\title{
Feather meal supplemented with protease in diets for meat-type quails
}

\section{Farinha de penas suplementadas com protease em dietas para codornas de corte}

\author{
Thiago Ferreira Diana ${ }^{1}$; Sandra Regina Freitas Pinheiro ${ }^{2 *}$; Karla Magalhães \\ Ramos $^{3}$, Cristina Moreira Bonafé4; Leilane Rocha Barros Dourado ${ }^{5}$; Andressa Silva \\ Santos $^{3}$; Felipe Santos Dalólio ${ }^{6}$
}

\begin{abstract}
The objective of this study was to evaluate the effect of the inclusion of feather meal (FM) in diets supplemented with protease for meat-type quails, on performance from eight to 21 days and from eight to 35 days of age and on carcass and cut yields economic profitability from eight to 35 days of age. A total of 360 male, meat-type quails, were allotted to a completely randomized design, in a factorial $3 \times 3$ arrangement (three diets and three FM levels of inclusion), with four replicates of 10 quails per experimental unit. The diets evaluated were positive control (PC) $+0 \% \mathrm{FM}, \mathrm{PC}+5 \% \mathrm{FM}, \mathrm{PC}+10 \%$ $\mathrm{FM}$, negative control (NC) $+0 \% \mathrm{FM}, \mathrm{NC}+5 \% \mathrm{FM}, \mathrm{NC}+10 \% \mathrm{FM}, \mathrm{NC}+0 \% \mathrm{FM}+$ protease, $\mathrm{NC}+$ $5 \% \mathrm{FM}+$ protease and $\mathrm{NC}+10 \% \mathrm{FM}+$ protease. The $\mathrm{NC}$ diet was formulated with a reduction in crude protein and amino acids, compared to the PC diet. There was an effect $(p<0.05)$ of the inclusion of FM in diets on feed intake, weight gain and feed conversion ratio, from eight to 21 and from eight to 35 days of age. There was a significant effect $(p<0.05)$ of FM inclusion on the live weight of 35-day-old quails. The inclusion of FM impairs meat-type quails' performance at all ages evaluated. NC diets, with and without protease, worsen the performance of birds compared to PC diets. Better economic profitability is observed for up to $5 \%$ inclusion of feather meal in positive control diets.
\end{abstract}

Key words: Alternative feedstuffs. Crude protein. Digestibility. Sulfur amino acids.

\section{Resumo}

Objetivou-se com este estudo avaliar o efeito da inclusão de farinha de penas (FP) em dietas suplementadas com protease para codornas de corte, no desempenho de oito a 21 dias e de oito a 35 dias de idade e o rendimento de carcaça e cortes e rentabilidade econômica de oito a 35 dias de idade. Um total de 360 codornas de corte, machos, foram distribuídas em delineamento inteiramente casualizado, em arranjo fatorial $3 \times 3$ (três dietas e três níveis de inclusão de FP), com quatro repetições de 10 codornas por unidade experimental. As dietas avaliadas foram controle positivo (CP) $+0 \% \mathrm{FP}, \mathrm{CP}+5 \% \mathrm{FP}, \mathrm{CP}+$ $10 \% \mathrm{FP}$, controle negativo $(\mathrm{CN})+0 \% \mathrm{FP}, \mathrm{CN}+5 \% \mathrm{FP}, \mathrm{CN}+10 \% \mathrm{FP}, \mathrm{CN}+0 \% \mathrm{FP}+$ protease, $\mathrm{CN}+$ $5 \% \mathrm{FP}+$ protease e $\mathrm{CN}+10 \% \mathrm{FP}+$ protease. A dieta $\mathrm{CN}$ foi formulada com redução na proteína bruta e aminoácidos, em comparação com a dieta $\mathrm{CP}$. Houve efeito $(\mathrm{p}<0,05)$ da inclusão de FP nas dietas sobre

1 Discente, Universidade Federal de Viçosa, UFV, Viçosa, MG, Brasil. E-mail: thiagofnet@hotmail.com

2 Prof ${ }^{a}$,UniversidadeFederal dos Vales do Jequitinhonhae Mucuri,UFVJM,Diamantina, MG,Brasil.E-mail:sandrafreitaspinheiro@, gmail.com

3 Discentes, UFVJM, Diamantina, MG, Brasil. E-mail: karlamramos@hotmail.com; andressa.s.ufvjm@gmail.com

4 Prof ${ }^{\mathrm{a}}$, UFVJM, Unaí, MG, Brasil. E-mail: crisbonafe@gmail.com

5 Prof ${ }^{\text {a }}$ Universidade Federal do Piauí, UFPI, Bom Jesus, PI, Brasil. E-mail: leilane@ufpi.edu.br

6 Pesquisador, Universidade Federal de Lavras, UFLA, Lavras, MG, Brasil. E-mail: felipesantos181@hotmail.com

${ }^{*}$ Author for correspondence

Received: Nov. 07, 2018 - Approved: May 08, 2019 
consumo de ração, ganho de peso e conversão alimentar, de oito a 21 e de oito a 35 dias de idade. Houve efeito significativo $(\mathrm{p}<0,05)$ da inclusão de FP sobre o peso vivo de codornas com 35 dias de idade. A inclusão de FP prejudica o desempenho das codornas de corte em todas as idades avaliadas. As dietas $\mathrm{CN}$, com e sem protease, pioram o desempenho das aves em relação às dietas $\mathrm{CP}$. Melhor rentabilidade econômica é observada para até $5 \%$ de inclusão de farinha de penas em dietas de controle positivo.

Palavras-chave: Alimentos alternativos. Aminoácidos sulfurados. Digestibilidade. Proteína bruta.

\section{Introduction}

The inclusion of feather meal (FM) in poultry diets reduces costs without negatively affecting performance. It also increases abattoirs' profits, especially for poultry integration, offering low costs in food production and poultry diet and a decrease in environmental pollution (BELLAVER et al., 2005; XAVIER et al., 2011; KHOSRAVINIA et al., 2015). Hydrolyzed FM is produced by cooking nondegraded feathers, obtained during the slaughter of poultry, under pressure. The FM has a minimum crude protein content of $80 \%$, with a variation of up to $2 \%$ and $3 \%$ in ethereal extract and mineral matter content respectively (BUTOLO, 2010). The high stability of proteins derived from FM results from a structural conformation in which there is a hydrophobic and ionic interaction within the $\beta$-keratin molecule, high numbers of cystine units and intra- and extra-chain disulfide bridges of certain amino acids that provide a high degree of insolubility (SCHROOYEN et al., 2001). Consequently, there is little activity of endogenous proteolytic enzymes, with low digestibility of FM (EYNG et al., 2012).

The process of hydrolysis of feathers from poultry abattoirs requires excellent temperatures and pressure-cooking times, and is subject to industrial standards, to give the FM good microbiological quality and adequate nutritional composition. Although excessive heat may destroy pathogenic microorganisms, it may also damage several amino acids which are highly sensitive to heat, such as methionine, histidine, lysine and tryptophan, whose concentration is very low in feathers (MARCONDES et al., 2008). Furthermore, derived non-assimilated amino acids may be formed, such as lysinoalanine and lanthionine, which decrease the nutritional quality of FM (GUPTA; RAMNANI, 2006; MARCONDES et al., 2008). Leeson and Summers (2001) affirm that lanthionine may occur as $20 \%$ or $30 \%$ of total cystine, which varies between $4.5 \%$ and $5.0 \%$, causing degradation in the digestibility of other amino acids. Hence, the amino acid balance of poultry diets is affected.

Although poultry produce naturally endogenous proteases which aid protein degradation, several more complex protein sources are not fully digested. According to Anjum and Chaudhry (2010) the use of protease decreases the costs of poultry diet, since it degrades proteins that are not easily digested, such as FM, to a considerable degree. Furthermore, due to genetic improvements in poultry, their amino acid requirements have increased, so that protein deposition can be maximized. Consequently, diets supplemented with protease may be viable for improving the use of dietary crude protein (ADEOLA, COWIESON, 2011).

Mahmood et al. (2018) registered the effect of diets supplemented with protease that contain 3\% of mixed meal made from poultry by-products, on the increase of nutrient digestibility, performance and carcass yield. Protease supplementation may be a good option in the nutrition of meat-type quails fed on diets with animal protein sources, such as FM. It aids the degradation of the protein fraction of the diet, the elimination of anti-nutritional factors and enzyme inhibitors and the productive performance.

In this context, the current assay evaluated the inclusion of different levels of feather meal in positive and negative control diets supplemented 
with protease, for meat-type quails during the periods eight to 21 days and eight to 35 days, on performance, carcass yield and cuts, together with the economic profitability index in the eight-to-35day phase.

\section{Materials and Methods}

The assay was performed at the Laboratory for Research on Monogastric Animals of the Universidade Federal dos Vales do Jequitinhonha e Mucuri (UFVJM), Diamantina, MG, Brazil, in January and February 2017. The experimental protocol was approved by the Committee for Ethics on Animals - CEUA (Protocol 26/2016) of UFVJM.

A total of 360 male, meat-type quails, eight days old with an average weight of $35 \pm 1.75 \mathrm{~g}$, were allotted to a completely randomized design, in a factorial 3 x 3 arrangement (three diets and three FM levels of inclusion), with four replicates of 10 quails per experimental unit (EU). The EUs consisted of galvanized wire cages, $60 \mathrm{~cm}$ long, $60 \mathrm{~cm}$ wide and $35 \mathrm{~cm}$ high, with $360 \mathrm{~cm}^{2} /$ quail, containing tile-like troughs and pressure-glass-like drinkers. Experimental treatments were: T1: positive control (PC) $+0 \%$ FM, T2: PC + 5\% FM, T3: PC $+10 \%$ FM, T4: negative control (NC) with an $8 \%$ reduction in crude protein and amino acids compared to PC (according to the recommendation of the company) $+0 \% \mathrm{FM}, \mathrm{T} 5: \mathrm{NC}+5 \% \mathrm{FM}, \mathrm{T} 6: \mathrm{NC}+10 \% \mathrm{FM}$, $\mathrm{T} 7: \mathrm{NC}+0 \% \mathrm{FM}+$ protease, $\mathrm{T} 8: \mathrm{NC}+5 \% \mathrm{FM}+$ protease and $\mathrm{T} 9: \mathrm{NC}+10 \% \mathrm{FM}+$ protease.

All experimental diets were provided as corn and soybean meal. Isoenergetic and equal-protein PC diets were formulated according to the quails' nutritional needs, following Silva and Costa (2009). NC diets were formulated with a decrease in crude protein and amino acid requirements, compared to PC diets. A protease enzyme (with serine characteristics) was also added to the diets, following the recommendations of the manufacturer $(0.020 \%)$ (Tables 1 and 2). Diets and water were provided ad libitum.
For the calculation of the experimental diets, previously carried out (unpublished data) determinations of the apparent metabolizable energy value of FM for quails, using the total excreta collection method, were used, following Sakomura and Rostagno (2016), giving a value of $3,006.65 \mathrm{kcal} \mathrm{kg}^{-1}$ in natural matter. The total amino acid levels considered for FM were as follows: aspartic acid (5.85\%), glutamic acid (8.81\%), alanine $(4.12 \%)$, arginine $(5.40 \%)$, cystine $(4.03 \%)$ and phenylalanine $(4.21 \%)$, following data from the manufacturer. Other amino acids followed Rostagno et al. (2011). Hydrolyzed FM has a digestibility in pepsin at levels of $1: 10,000$ in $0.2 \% \mathrm{HCl}(0.075 \mathrm{~N})$ of at least $65 \%$. The bromatological composition of the other ingredients followed data given by Rostagno et al. (2011).

Temperatures were monitored daily at 08:00 using a maximum and minimum thermometer, together with relative air humidity. Means were calculated at the end of the assay. The initial phase had a maximum mean of $28.8^{\circ} \mathrm{C}$ and a minimum mean of $25.1^{\circ} \mathrm{C}$, with $69 \%$ relative air humidity. Data for the entire phase were $27.7^{\circ} \mathrm{C}$ (maximum), $24.16^{\circ} \mathrm{C}$ (minimum) and $74 \%$ air humidity.

The performance of the quails at the $21^{\text {st }}$ and $35^{\text {th }}$ days was calculated via the parameters of feed intake (g/quail), body weight gain (g/quail) and feed conversion ratio $(\mathrm{g} / \mathrm{g})$. Feed intake was evaluated according to the difference between the amount of feed provided and the surplus at the end of the period, corrected by mortality data if necessary, following Sakomura and Rostagno (2016). Quails were weighed at the start and end of each phase to determine weight gain. The feed conversion ratio was calculated via the relationship between feed intake and body weight gain.

After 35 days, three quails were removed from each experimental unit to evaluate carcass yield and prime cuts (breast and thigh plus drumstick). Quails were tagged, weighed one by one and submitted to a six-hour food fast. They were then 
laid down, plucked, eviscerated, cut and weighed. the prime cuts yield was given as the proportion Parameters comprised live weight (g) and carcass of eviscerated carcass weight, without feathers, and noble cuts yields (\%). Carcass yield was given legs, head and neck (weight of part x 100/carcass as the ratio of the quail's weight on killing to its weight), according Pinheiro et al. (2015).

live weight (carcass weight $\mathrm{x}$ 100/live weight) and

Table 1. Percentage composition and calculated nutritional values of diets for quails (eight to 21 days).

\begin{tabular}{|c|c|c|c|c|c|c|c|c|c|}
\hline Ingredients & $\mathrm{T} 1$ & $\mathrm{~T} 2$ & T3 & $\mathrm{T} 4$ & $\mathrm{~T} 5$ & T6 & $\mathrm{T} 7$ & T8 & T9 \\
\hline Corn & 47.99 & 50.69 & 57.19 & 54.68 & 60.29 & 61.82 & 54.61 & 60.28 & 61.87 \\
\hline Soybean meal & 45.54 & 35.68 & 25.43 & 39.98 & 29.86 & 20.50 & 39.98 & 29.87 & 20.43 \\
\hline Soybean oil & 2.49 & 4.34 & 2.99 & 1.37 & 0.00 & 0.018 & 1.39 & 0.00 & 0.00 \\
\hline Limestone & 1.25 & 1.34 & 1.32 & 1.25 & 1.32 & 1.387 & 1.26 & 1.32 & 1.39 \\
\hline Dicalcium phosphate & 1.04 & 0.94 & 0.85 & 1.07 & 1.00 & 0.93 & 1.08 & 1.00 & 0.93 \\
\hline Salt & 0.38 & 0.34 & 0.31 & 0.38 & 0.35 & 0.32 & 0.38 & 0.35 & 0.32 \\
\hline Mineral supplement ${ }^{1}$ & 0.20 & 0.20 & 0.20 & 0.20 & 0.20 & 0.20 & 0.20 & 0.20 & 0.20 \\
\hline Vitamin supplement ${ }^{2}$ & 0.20 & 0.20 & 0.20 & 0.20 & 0.20 & 0.20 & 0.20 & 0.20 & 0.20 \\
\hline L-Lysine $\mathrm{HCl}(78 \%)$ & 0.14 & 0.36 & 0.58 & 0.16 & 0.38 & 0.58 & 0.17 & 0.38 & 0.58 \\
\hline L-Isoleucine $(98.5 \%)$ & 0.15 & 0.30 & 0.35 & 0.15 & 0.18 & 0.20 & 0.15 & 0.18 & 0.20 \\
\hline DL-Methionine (98\%) & 0.39 & 0.36 & 0.32 & 0.35 & 0.31 & 0.28 & 0.35 & 0.31 & 0.28 \\
\hline L-Tryptophan (98\%) & 0.00 & 0.00 & 0.00 & 0.00 & 0.02 & 0.00 & 0.00 & 0.02 & 0.06 \\
\hline L-Treonine (99\%) & 0.22 & 0.24 & 0.25 & 0.20 & 0.20 & 0.21 & 0.20 & 0.20 & 0.21 \\
\hline Antioxidant $^{3}$ & 0.01 & 0.01 & 0.01 & 0.01 & 0.01 & 0.01 & 0.01 & 0.01 & 0.01 \\
\hline Inert $^{4}$ & 0.00 & 0.00 & 0.00 & 0.00 & 0.68 & 3.34 & 0.00 & 0.66 & 3.30 \\
\hline Protease & 0.00 & 0.00 & 0.00 & 0.00 & 0.00 & 0.00 & 0.02 & 0.02 & 0.02 \\
\hline \multicolumn{10}{|c|}{ Calculated Composition } \\
\hline Metabolizable energy $(\mathrm{kcal} / \mathrm{kg})$ & 2.900 & 2.900 & 2.900 & 2.900 & 2.900 & 2.900 & 2.900 & 2.900 & 2.900 \\
\hline Calcium (\%) & 0.85 & 0.85 & 0.85 & 0.85 & 0.85 & 0.85 & 0.85 & 0.85 & 0.85 \\
\hline Non-phytate phosphorus (\%) & 0.32 & 0.32 & 0.32 & 0.32 & 0.32 & 0.32 & 0.32 & 0.32 & 0.32 \\
\hline Sodium $(\%)$ & 0.17 & 0.17 & 0.17 & 0.17 & 0.17 & 0.17 & 0.17 & 0.17 & 0.17 \\
\hline Crude protein (\%) & 25.00 & 25.00 & 25.00 & 23.00 & 23.00 & 23.00 & 23.00 & 23.00 & 23.00 \\
\hline Digestible arginine $(\%)$ & 1.61 & 1.52 & 1.44 & 1.45 & 1.38 & 1.31 & 1.45 & 1.38 & 1.31 \\
\hline Digestible isoleucine (\%) & 1.14 & 1.14 & 1.14 & 1.05 & 1.05 & 1.05 & 1.05 & 1.05 & 1.05 \\
\hline Digestible leucine (\%) & 1.88 & 1.84 & 1.83 & 1.77 & 1.76 & 1.74 & 1.77 & 1.76 & 1.74 \\
\hline Digestible lysine (\%) & 1.37 & 1.37 & 1.37 & 1.26 & 1.26 & 1.26 & 1.26 & 1.26 & 1.26 \\
\hline Digestible methionine + cystine $(\%)$ & 1.04 & 1.04 & 1.04 & 0.96 & 0.96 & 0.96 & 0.96 & 0.96 & 0.96 \\
\hline Digestible treonine $(\%)$ & 1.04 & 1.04 & 1.04 & 0.96 & 0.96 & 0.96 & 0.96 & 0.96 & 0.96 \\
\hline Digestible tryptophan (\%) & 0.29 & 0.25 & 0.22 & 0.26 & 0.25 & 0.25 & 0.26 & 0.25 & 0.25 \\
\hline Digestible valine $(\%)$ & 1.06 & 1.09 & 1.15 & 0.97 & 1.02 & 1.08 & 0.97 & 1.02 & 1.08 \\
\hline
\end{tabular}

${ }^{1}$ Per kilogram of product: Copper $2500.00 \mathrm{mg}$, Choline $27.00 \mathrm{mg}$, Iron $12.5 \mathrm{mg}$, Iodine $250.00 \mathrm{mg}$, Manganese $7.5 \mathrm{mg}$, Methionine 130.00 g, Selenium $20.00 \mathrm{mg}$, Sodium $120.00 \mathrm{~g}$, Zinc $4500.00 \mathrm{mg} .{ }^{2}$ Per kilogram of product: Folic Acid $175.00 \mathrm{mg}$, Nicotinic Acid 28.000.00 mg, Pantothenic Acid 2500.00 mg, Zinc Bacitracin 5100.00 mg, BHA 500.00 mg, BHT 500.00 mg, Biotin 12.50 mg, Vitamin A 500.000.00 IU, Vitamin B1 $150.00 \mathrm{mg}$, Vitamin B12 $2500.00 \mathrm{mg}$, Vitamin B2 $800.00 \mathrm{mg}$, Vitamin B6 $250.00 \mathrm{mg}$, Vitamin D3 170.000.00 IU, Vitamin E 2100.00 IU, Vitamin K3 $400.00 \mathrm{mg}$, Salinomycin $12500.00 \mathrm{mg} / \mathrm{kg} .{ }^{3}$ Butil hydroxytoluene. ${ }^{4}$ Washed thin sand. 
Table 2. Percentage composition and calculated nutritional values of diets for quails (22 to 35 days).

\begin{tabular}{|c|c|c|c|c|c|c|c|c|c|}
\hline Ingredients & $\mathrm{T} 1$ & $\mathrm{~T} 2$ & T3 & $\mathrm{T} 4$ & T5 & T6 & $\mathrm{T} 7$ & T8 & T9 \\
\hline Corn & 55.42 & 62.18 & 68.47 & 62.20 & 68.69 & 70.96 & 62.03 & 68.88 & 70.96 \\
\hline Soybeanmeal & 38.65 & 28.58 & 18.38 & 32.93 & 21.76 & 13.41 & 33.05 & 21.72 & 13.40 \\
\hline Soybean oil & 3.35 & 1.59 & 0.00 & 2.21 & 0.78 & 0.30 & 2.25 & 0.72 & 0.30 \\
\hline Limestone & 1.03 & 1.11 & 1.17 & 1.04 & 1.10 & 1.17 & 1.03 & 1.10 & 1.17 \\
\hline Dicalcium phosphate & 0.82 & 0.74 & 0.66 & 0.86 & 0.80 & 0.71 & 0.87 & 0.80 & 0.71 \\
\hline Salt & 0.33 & 0.30 & 0.26 & 0.31 & 0.30 & 0.27 & 0.33 & 0.29 & 0.27 \\
\hline Mineral supplement ${ }^{1}$ & 0.05 & 0.05 & 0.05 & 0.05 & 0.05 & 0.05 & 0.05 & 0.05 & 0.05 \\
\hline Vitamin supplement ${ }^{2}$ & 0.10 & 0.10 & 0.10 & 0.10 & 0.10 & 0.10 & 0.10 & 0.10 & 0.10 \\
\hline L-Lysine $\mathrm{HCl}(78 \%)$ & 0.00 & 0.11 & 0.32 & 0.00 & 0.21 & 0.37 & 0.00 & 0.21 & 0.38 \\
\hline L-Isoleucine $(98.5 \% \%)$ & 0.02 & 0.05 & 0.07 & 0.05 & 0.09 & 0.09 & 0.04 & 0.09 & 0.09 \\
\hline Dl-Methionine (98\%) & 0.20 & 0.16 & 0.12 & 0.19 & 0.16 & 0.11 & 0.19 & 0.16 & 0.11 \\
\hline L-Treonine (99\%) & 0.02 & 0.02 & 0.03 & 0.04 & 0.05 & 0.04 & 0.03 & 0.05 & 0.04 \\
\hline Antioxidant ${ }^{3}$ & 0.01 & 0.01 & 0.01 & 0.01 & 0.01 & 0.01 & 0.01 & 0.01 & 0.01 \\
\hline Inert $^{4}$ & 0.00 & 0.00 & 0.33 & 0.00 & 0.90 & 2.41 & 0.00 & 0.80 & 2.39 \\
\hline Protease & 0.00 & 0.00 & 0.00 & 0.00 & 0.00 & 0.00 & 0.02 & 0.02 & 0.02 \\
\hline \multicolumn{10}{|c|}{ Calculated Composition } \\
\hline Metabolizable & 3.050 & 3.050 & 3.050 & 3.050 & 3.050 & 3.050 & 3.050 & 3.050 & 3.050 \\
\hline Calcium (\%) & 0.70 & 0.70 & 0.70 & 0.70 & 0.70 & 0.70 & 0.70 & 0.70 & 0.70 \\
\hline Non-phytate phosphorus (\%) & 0.27 & 0.27 & 0.27 & 0.27 & 0.27 & 0.27 & 0.27 & 0.27 & 0.27 \\
\hline Sodium $(\%)$ & 0.15 & 0.15 & 0.15 & 0.15 & 0.15 & 0.15 & 0.15 & 0.15 & 0.15 \\
\hline Crude protein $(\%)$ & 22.00 & 22.00 & 22.00 & 19.96 & 19.56 & 20.00 & 20.00 & 19.56 & 20.00 \\
\hline Digestible arginine (\%) & 1.41 & 1.34 & 1.27 & 1.26 & 1.15 & 1.12 & 1.26 & 1.15 & 1.12 \\
\hline Digestible isoleucine (\%) & 0.90 & 0.90 & 0.90 & 0.82 & 0.82 & 0.82 & 0.82 & 0.82 & 0.82 \\
\hline Digestible lysine (\%) & 1.02 & 1.02 & 1.02 & 0.96 & 0.94 & 0.94 & 0.97 & 0.94 & 0.94 \\
\hline Digestible methionine+cystine $(\%)$ & 0.80 & 0.80 & 0.80 & 0.74 & 0.74 & 0.74 & 0.74 & 0.74 & 0.74 \\
\hline Digestible treonine $(\%)$ & 0.78 & 0.78 & 0.78 & 0.72 & 0.72 & 0.72 & 0.72 & 0.72 & 0.72 \\
\hline Digestible tryptophan (\%) & 0.25 & 0.22 & 0.18 & 0.22 & 0.18 & 0.16 & 0.22 & 0.18 & 0.16 \\
\hline Digestible valine (\%) & 0.94 & 1.00 & 1.06 & 0.85 & 0.89 & 0.97 & 0.86 & 0.89 & 0.97 \\
\hline
\end{tabular}

${ }^{1}$ Per kilogram of product: Copper $2500.00 \mathrm{mg}$. Choline $27.00 \mathrm{mg}$. Iron $12.5 \mathrm{mg}$. Iodine $250.00 \mathrm{mg}$. Manganese $7.5 \mathrm{mg}$. Methionine 130.00 g. Selenium $20.00 \mathrm{mg}$. Sodium 120.00 g. Zinc $4500.00 \mathrm{mg} .{ }^{2}$ Per kilogram of product: Folic Acid $175.00 \mathrm{mg}$. Nicotinic Acid 28.000.00 mg. Pantothenic Acid 2500.00 mg. Zinc Bacitracin 5100.00 mg. BHA 500.00 mg. BHT 500.00 mg. Biotin 12.50 mg. Vitamin A 500.000.00 IU. Vitamin B1 $150.00 \mathrm{mg}$. Vitamin B12 $2500.00 \mathrm{mg}$. Vitamin B2 $800.00 \mathrm{mg}$. Vitamin B6 $250.00 \mathrm{mg}$. Vitamin D3 170.000.00 IU. Vitamin E 2100.00 IU. Vitamin K3 $400.00 \mathrm{mg}$. Salinomycin $12500.00 \mathrm{mg} / \mathrm{kg}$. ${ }^{3}$ Butil hydroxytoluene. ${ }^{4}$ Washed thin sand.

The economic profitability of treatments was determined according to calculations given by Barbosa et al. (2017), where profitability index indicates the profit obtained for each Brazilian real spent per kilo of diet consumed by the meat-type quails. Calculated variables used in the analysis of profitability included mean gross profit, profit index and mean gross margin. Mean gross profit (MGP) is the product of quantity produced $(\mathrm{Q})$ multiplied by the product's selling price (PSP). Mean feeding cost (MFC) is the amount of diet consumed (DC) multiplied by the mean diet cost (MDC). Mean gross margin (MGM) is the difference between mean gross profit (MGP) and mean feeding cost (MFC). Profitability (PI) is the quotient of MGM and MFC, multiplied by 100 .

Feed costs only were considered in calculating profits. Live weight was obtained by calculating the mean weight of quails prior to fasting at 35 days. 
The mean price per kilo of live quails ( $\mathrm{R} \$ 8.50)$ was that given by the market in Diamantina, MG, Brazil. However, the price of diet per kilo was calculated from the prices of the ingredients of each diet in February 2017.

The data were submitted to an analysis of variance, to identify possible main effects or interactions of the studied factors. To obtain the best diet, means were compared using the Student-Newman-Keuls test at the $5 \%$ probability level. When a significant $(p<0.05)$ effect of dietary FM level was detected in the analysis of variance, a regression analysis was performed. In order to check the best adjustment of the data, the sum of squared deviations, the significance of the F-test and the coefficient of determination were considered. Statistical analyses were calculated using the System for Statistical and Genetic Analyses - UFV (SAEG, 2007).

\section{Results and Discussion}

An interaction effect $(p<0.05)$ was observed for the diets and FM for feed intake of meat-type quails during the period eight to 21 days (Table 3 ). The feed intake of the quails fed with the PC diet decreased linearly with increasing FM (FI $=217.10$ $\left.1.94 \mathrm{FM}, \mathrm{R}^{2}=0.61\right)$. However, when fed with the $\mathrm{NC}$ diet, an increasing inclusion of FM resulted in higher feed intake up to $4.23 \%$ of FM in the diet, according to the equation $\mathrm{FI}=206.90+4.54 \mathrm{FM}$ $0.537 \mathrm{FM}^{2}, \mathrm{R}^{2}=0.39$. The birds fed the $\mathrm{NC}$ diet supplemented with protease and higher levels of FM presented a linear decrease in feed intake (FI = 211.26-1.222 FM, $\mathrm{R}^{2}=0.39$ ). The results observed demonstrated the benefits of employing up to $4.23 \%$
FM in negative control diets for 21-day-old quails. It is a well-known fact that the protein of FM has high levels of keratin in its structural conformation, and this is insoluble and resistant to the proteolithic activity of trypsin and pepsin in monogastric animals (FARAG; HASSAN, 2004; PACHECO et al., 2016; DING et al., 2016). Santos et al. (2006) similarly reported that the protein in FM had low biological values and caused a reduction of feed intake in European quails fed with FM at one to 21 days old.

Similarly, there was an effect of diet and FM inclusion on body weight gain $(p<0.05)$. The quails fed with the PC diet presented higher weight gain (7\%) compared with $\mathrm{NC}$, with and without protease. An increase in FM in the diet resulted in a linear decrease in weight gain: $\mathrm{WG}=104.53-1.336 \mathrm{FM}$, $\mathrm{R}^{2}=0.41$. The lower feed intake observed in quails fed with highest levels of FM justify the results observed for the weight gain. Several researchers have indicated a maximum limit of $4 \%$ inclusion of FM without any loss of performance (XAVIER et al., 2011; ROSTAGNO et al., 2011). However, Holanda et al. (2009) evaluated increasing levels of FM inclusion in diets for broiler chickens, aged seven to 42 days, and concluded that up to $8 \%$ may be employed without any loss in production. Brandelli et al. (2015) also reported that the quality of FM in animal feed is dependent on its production and processing prior to use in diets. In fact, inadequate processing may cause contamination by pathogenic microorganisms and complexation of proteins and amino acids causing the amino acid balance of poultry diets to be affected, with a consequent reduction of performance in the eight-to-21-day phase. 
Table 3. Means and standard deviation of the mean of feed intake (FI), body weight gain (BWG) and feed conversion ratio (FCR) of meat-type quails fed diets containing feather meal (FM) and protease in diets positive and negative control, from eight to 21 days of age.

\begin{tabular}{|c|c|c|c|c|c|c|c|c|c|}
\hline \multirow[t]{2}{*}{ Parameters } & \multirow[t]{2}{*}{ Diet } & \multicolumn{3}{|c|}{ Feather meal (\%) } & \multirow{2}{*}{ Means } & \multirow{2}{*}{$\begin{array}{l}\text { CV } \\
(\%)\end{array}$} & \multicolumn{3}{|c|}{ P-value } \\
\hline & & 0 & 5 & 10 & & & Diet & FM & Diet*FM \\
\hline \multirow{4}{*}{ FI (g) } & $\mathrm{PC}$ & $219.30 \pm 1.57$ & $202.90 \pm 7.71$ & $199.90 \pm 7.54$ & 207.40 & \multirow{4}{*}{3.53} & \multirow{4}{*}{0.7016} & \multirow{4}{*}{0.0004} & \multirow{4}{*}{0.0288} \\
\hline & $\mathrm{NC}$ & $206.90 \pm 6.40$ & $216.20 \pm 8.81$ & $198.60 \pm 9.24$ & 207.20 & & & & \\
\hline & NCPROT & $210.90 \pm 5.13$ & $205.90 \pm 6.79$ & $198.70 \pm 9.16$ & 205.20 & & & & \\
\hline & Means & 212.40 & 208.30 & 199.10 & & & & & \\
\hline \multirow{4}{*}{ BWG (g) } & $\mathrm{PC}$ & $109.70 \pm 2.66$ & $103.60 \pm 3.07$ & $94.70 \pm 2.15$ & $102.70 \mathrm{a}$ & \multirow{4}{*}{5.33} & \multirow{4}{*}{0.0022} & \multirow{4}{*}{$<0.0001$} & \multirow{4}{*}{0.0519} \\
\hline & $\mathrm{NC}$ & $97.40 \pm 7.27$ & $103.50 \pm 5.37$ & $86.00 \pm 6.48$ & $95.60 \mathrm{~b}$ & & & & \\
\hline & NCPROT & $102.90 \pm 5.32$ & $93.80 \pm 5.71$ & $89.10 \pm 6.26$ & $95.30 \mathrm{~b}$ & & & & \\
\hline & Means & 103.30 & 100.30 & 89.90 & & & & & \\
\hline \multirow{4}{*}{ FCR (g/g) } & $\mathrm{PC}$ & $2.000 \pm 0.03$ & $1.958 \pm 0.07$ & $2.112 \pm 0.10$ & $2.023 \mathrm{~b}$ & \multirow{4}{*}{4.31} & \multirow{4}{*}{0.0004} & \multirow{4}{*}{0.0004} & \multirow{4}{*}{0.1647} \\
\hline & $\mathrm{NC}$ & $2.132 \pm 0.12$ & $2.092 \pm 0.06$ & $2.314 \pm 0.08$ & $2.179 \mathrm{a}$ & & & & \\
\hline & NCPROT & $2.054 \pm 0.09$ & $2.199 \pm 0.10$ & $2.234 \pm 0.01$ & $2.162 \mathrm{a}$ & & & & \\
\hline & Means & 2.062 & 2.083 & 2.220 & & & & & \\
\hline
\end{tabular}

PC: Positive control. NC: Negative control. NCPROT: Negative control with protease. CV: Coefficient of variation (\%). Means within the same parameter with different superscripts are significantly different $(\mathrm{p}<0.05)$.

The best feed conversion ratio was obtained in quails fed with the PC diet, while those fed the NC and $\mathrm{NC}$ with protease diets presented the worst feed conversion ratios. Due to the reduction in weight gain in birds fed with the NC diet, with and without protease, together with the similar feed intake, the quails presented a worse feed conversion ratio. Increasing levels of FM in the diets led to worse feed conversion ratios, according to the linear equation $\mathrm{FCR}=2.043+0.0158 \mathrm{FM}, \mathrm{R}^{2}=0.23$. Macari and Maiorka (2017) reported that, during the initial phase, poultry have a developing fledging gastrointestinal system. Furthermore, Alleman et al. (2000) insisted on the difficulty poultry have in the digestion of ingredients derived from animals, such as FM. In fact, FM contains more complex proteins (complex tertiary structures) and poultry fail to produce specific proteolithic enzymes synthesized by the pancreas and intestinal mucus.

During the total period (eight to 35 days old) there was no interaction between FM inclusion and diets $(p>0.05)$ for any of the performance variables (Table 4). Higher feed intake, higher body weight gain and better feed conversion ratios were found in the quails for the PC diet, compared to the $\mathrm{NC}$ diet, with and without protease supplementation. According to Nunes et al. (2015) the nutrient and energy reductions of the NC treatment effectively allow for the statistical performance differentiation from the PC diet. In the present study, it was also observed that the reduction of crude protein and amino acids in the $\mathrm{NC}$ diets, compared to the PC diets, allowed effective differentiation of the variation in the performance of the quails. Reducing the levels of crude protein and amino acids in the diets of quails resulted in worse performance, since a minimum level of these nutrients is required to maintain performance. Sklan and Plavnik (2002) reported that diets of broilers should be formulated to provide sufficient amino acids for protein synthesis. Lower growth and reduction in food efficiency with low ingestion of crude protein, can be attributed to limited amounts of essential amino acids or insufficient amounts of non-essential amino acids. This result is corroborated by Dean et al. (2006), who report that most assays with a reduction of crude protein of up to $4 \%$ result in decreased performance and efficiency in poultry growth, even 
though other nutritional requirements are satisfied. Rabie et al. (2015) corroborated this fact when they detected a decrease in the performance of meattype quails during the 14-to-42-day-old phase, with diets with up to $4 \%$ reduction in crude protein level supplemented with protease. Some results reported in the literature (CORRÊA et al., 2007; TEIXEIRA et al., 2013) suggest that meat-type quails in the growth phase require 3,100 $\mathrm{kcal} \mathrm{ME} \mathrm{kg}^{-1}$ and $23 \%$ and $24.8 \%$ of crude protein respectively.

Table 4. Means and standard deviation of the mean of feed intake (FI), body weight gain (WG) and feed conversion ratio (FCR) of meat-type quails fed diets containing feather meal (FM) and protease in diets positive and negative control, from eight to 35 days of age.

\begin{tabular}{|c|c|c|c|c|c|c|c|c|c|}
\hline \multirow[t]{2}{*}{ Parameters } & \multirow[t]{2}{*}{ Diet } & \multicolumn{3}{|c|}{ Feather meal (\%) } & \multirow{2}{*}{ Means } & \multirow{2}{*}{$\begin{array}{l}\text { CV } \\
(\%)\end{array}$} & \multicolumn{3}{|c|}{ P-value } \\
\hline & & 0 & 5 & 10 & & & Diet & FM & Diet*FP \\
\hline \multirow{4}{*}{ FI (g) } & $\mathrm{PC}$ & $534.90 \pm 15.91$ & $509.10 \pm 9.60$ & $507.80 \pm 24.57$ & 517.30 & \multirow{4}{*}{3.7} & \multirow{4}{*}{0.7144} & \multirow{4}{*}{0.0068} & \multirow{4}{*}{0.6879} \\
\hline & $\mathrm{NC}$ & $524.70 \pm 22.65$ & $520.40 \pm 11.35$ & $499.10 \pm 17.01$ & 514.70 & & & & \\
\hline & NCPROT & $521.70 \pm 15.87$ & $517.50 \pm 20.27$ & $493.60 \pm 26.85$ & 510.90 & & & & \\
\hline & Means & 527.10 & 515.70 & 500.20 & & & & & \\
\hline \multirow{4}{*}{ BWG (g) } & $\mathrm{PC}$ & $207.10 \pm 5.79$ & $191.30 \pm 4.71$ & $177.00 \pm 5.29$ & $191.80 \mathrm{a}$ & \multirow{4}{*}{5.95} & \multirow{4}{*}{0.0002} & \multirow{4}{*}{$<0.0001$} & \multirow{4}{*}{0.3300} \\
\hline & $\mathrm{NC}$ & $179.30 \pm 18.00$ & $174.20 \pm 8.10$ & $164.90 \pm 11.91$ & $172.80 \mathrm{~b}$ & & & & \\
\hline & NCPROT & $193.30 \pm 4.22$ & $168.70 \pm 15.16$ & $159.80 \pm 12.72$ & $173.80 \mathrm{~b}$ & & & & \\
\hline & Means & 193.20 & 178.10 & 167.20 & & & & & \\
\hline \multirow{4}{*}{$\mathrm{FCR}(\mathrm{g} / \mathrm{g})$} & $\mathrm{PC}$ & $2.583 \pm 0.02$ & $2.663 \pm 0.08$ & $2.869 \pm 0.09$ & $2.705 b$ & \multirow{4}{*}{5.42} & \multirow{4}{*}{0.0002} & \multirow{4}{*}{0.0016} & \multirow{4}{*}{0.1459} \\
\hline & $\mathrm{NC}$ & $2.947 \pm 0.31$ & $2.994 \pm 0.18$ & $3.034 \pm 0.13$ & $2.992^{\mathrm{a}}$ & & & & \\
\hline & NCPROT & $2.701 \pm 0.11$ & $3.078 \pm 0.17$ & $3.094 \pm 0.09$ & $2.958 \mathrm{a}$ & & & & \\
\hline & Means & 2.744 & 2.912 & 2.999 & & & & & \\
\hline
\end{tabular}

PC: Positive control. NC: Negative control. NCPROT: Negative control with protease. CV: Coefficient of variation (\%). Means within the same parameter with different superscripts are significantly different $(p<0.05)$.

Increasing the FM in diets results in a linear decrease in feed intake $\left(\mathrm{FI}=527.79-2.694 \mathrm{FM}, \mathrm{R}^{2}\right.$ $=0.28)$ and body weight gain $(\mathrm{BWG}=192.4-2.596$ $F M, R^{2}=0.39$ ), while feed conversion ratio showed the opposite trend $\left(\mathrm{FCR}=2.757+0.0255 \mathrm{FM}, \mathrm{R}^{2}\right.$ $=0.21)$. This observation questions the nutrient utilization of FM by the quails. We speculated that a high keratin content plays a crucial role in this regard, arising from the poor amino acids and crude protein utilization by quails. Protease did not have a positive effect on the degradation of the protein in FM. Since enzymes are specific for each substrate, it depends on the ingredients' chemical composition (LEITE et al., 2011). Consequently, in the case of the current analysis, protease failed to exhibit its role in the degradation of keratin in FM. The protease under analysis did not improve digestion and further absorption of protein, since it was not specific for the degradation of keratin; consequently, quails fed on diets including protease did not have the highest body weight gain. Nunes et al. (2015) reported that, among other reasons, the enzyme supplementation may not have been efficient enough to allow for similar performance as that obtained with the standard diet (PC), due to the higher lipid (oil) level of the diet, which has less impact on the heat increment compared with carbohydrates and proteins. These results are in agreement with those of our study.

Meyer et al. (2012) stated that a 5\% inclusion of FM in the diet of laying hens increases the concentration of keratinolytic bacteria in the ileum and caecum but reduces the Shannon index which describes the uniformity and diversity of intestinal bacteria. The above may indicate that inclusion of FM above $5 \%$ in poultry diet harms the 
digestive processes and may increase pathogenic bacteria. Further studies are required to evaluate bacteria populations, the efficiency of digestive and fermentation processes and the use of feed additives such as exogenous proteases and intestine microflora balance producers, in poultry diets.
There was a significant effect $(p<0.05)$ only for the live weight of 35-day-old quails (Table 5). Quails fed on diets with increased FM had decreased live weights, according to the linear equation $\mathrm{LW}=$ 222.02-1.351 FM, $\mathrm{R}^{2}=0.31$. Again, this lower live weight may be due to the high keratin content in feather meal leading to poor nutrient utilization by birds.

Table 5. Means and standard deviation of the mean of live weight (LW), carcass yield (CY), breast yield (BY) and thigh and drumstick yield (TDY) of meat-type quails fed diets containing feather meal (FM) and protease in diets positive and negative control, at 35 days of age.

\begin{tabular}{|c|c|c|c|c|c|c|c|c|c|}
\hline \multirow[t]{2}{*}{ Parameters } & \multirow[t]{2}{*}{ Diet } & \multicolumn{3}{|c|}{ Feather meal (\%) } & \multirow{2}{*}{ Means } & \multirow{2}{*}{$\begin{array}{l}\text { CV } \\
(\%)\end{array}$} & \multicolumn{3}{|c|}{ P-value } \\
\hline & & 0 & 5 & 10 & & & Diet & FM & Diet*FM \\
\hline \multirow{4}{*}{$\mathrm{LW}(\mathrm{g})$} & $\mathrm{PC}$ & $221.90 \pm 10.45$ & $219.10 \pm 8.61$ & $216.70 \pm 9.85$ & 219.20 & \multirow{4}{*}{3.45} & \multirow{4}{*}{0.907} & \multirow{4}{*}{0.0005} & \multirow{4}{*}{0.0648} \\
\hline & $\mathrm{NC}$ & $222.40 \pm 3.33$ & $211.30 \pm 7.73$ & $207.30 \pm 4.65$ & 213.70 & & & & \\
\hline & NCPROT & $219.30 \pm 1.44$ & $220.30 \pm 4.23$ & $198.90 \pm 10.13$ & 212.80 & & & & \\
\hline & Means & 221.20 & 216.90 & 207.60 & & & & & \\
\hline \multirow{4}{*}{$\mathrm{CY}(\%)$} & $\mathrm{PC}$ & $77.10 \pm 0.88$ & $77.70 \pm 1.17$ & $75.40 \pm 1.32$ & 76.70 & \multirow{4}{*}{2.01} & \multirow{4}{*}{0.4201} & \multirow{4}{*}{0.4209} & \multirow{4}{*}{0.6100} \\
\hline & $\mathrm{NC}$ & $75.90 \pm 0.95$ & $76.00 \pm 1.49$ & $75.90 \pm 2.47$ & 75.90 & & & & \\
\hline & NCPROT & $76.20 \pm 1.01$ & $76.00 \pm 2.23$ & $75.90 \pm 1.39$ & 76.00 & & & & \\
\hline & Means & 76.40 & 76.60 & 75.70 & & & & & \\
\hline \multirow{4}{*}{ BY $(\%)$} & $\mathrm{PC}$ & $34.50 \pm 1.33$ & $35.20 \pm 0.94$ & $34.60 \pm 0.66$ & 34.80 & \multirow{4}{*}{3.59} & \multirow{4}{*}{0.1681} & \multirow{4}{*}{0.507} & \multirow{4}{*}{0.8776} \\
\hline & $\mathrm{NC}$ & $35.20 \pm 0.88$ & $35.50 \pm 1.05$ & $35.00 \pm 0.77$ & 35.20 & & & & \\
\hline & NCPROT & $36.30 \pm 1.83$ & $35.97 \pm 2.10$ & $35.20 \pm 1.05$ & 35.80 & & & & \\
\hline & Means & 35.30 & 35.50 & 34.90 & & & & & \\
\hline \multirow{4}{*}{ TDY(\%) } & $\mathrm{PC}$ & $24.30 \pm 0.69$ & $24.30 \pm 0.31$ & $24.20 \pm 0.58$ & 24.30 & \multirow{4}{*}{2.22} & \multirow{4}{*}{0.1303} & \multirow{4}{*}{0.2776} & \multirow{4}{*}{0.2754} \\
\hline & $\mathrm{NC}$ & $24.70 \pm 0.34$ & $24.70 \pm 0.37$ & $24.80 \pm 0.39$ & 24.70 & & & & \\
\hline & NCPROT & $24.80 \pm 0.38$ & $23.90 \pm 0.85$ & $24.90 \pm 0.57$ & 24.50 & & & & \\
\hline & Means & 24.60 & 24.30 & 24.60 & & & & & \\
\hline
\end{tabular}

PC: Positive control. NC: Negative control. NCPROT: Negative control with protease. CV: Coefficient of variation (\%).

Santos et al. (2006) did not detect any effect on carcass, breast or thigh plus drumstick weight when they assessed different levels of FM in the feed of 42-day-old meat-type quails. The authors recommended a maximum $9 \%$ inclusion of $\mathrm{FM}$ without any decrease in carcass parameters. Hasni et al. (2014) also reported non-significant differences in carcass yield in broilers fed with up to $3.15 \%$ FM.
Analysis of the economic profitability revealed that $\mathrm{PC}$ diets with $0 \%$ and $5 \%$ inclusion of $\mathrm{FM}$, and $\mathrm{NC}$ diets with $0 \% \mathrm{FM}$ supplemented with protease, had better results for mean gross profit (Table 6). The best result occurred for PC with $0 \% \mathrm{FM}$. The mean feed cost for the PC diet with $0 \%$ FM and without protease supplementation was R $\$ 0.67$, which was higher than for the other diets. Higher costs were due to a greater inclusion of soybean meal and oil. 
Table 6. Economic profitability analysis of productive meat-type quails fed diets containing feather meal (FM) and protease at 35 days of age.

\begin{tabular}{lcccc}
\hline Treatment & MGP (R \$quail) & MFC (R \$quail) & MDC (R \$quail) & PI (\%) \\
\hline PC (0\% FM) & 1.76 & 0.67 & 1.08 & 1.61 \\
PC (5\% FM) & 1.62 & 0.62 & 1.00 & 1.61 \\
PC (10\% FM) & 1.50 & 0.61 & 0.89 & 1.45 \\
NC (0\% FM) & 1.52 & 0.64 & 0.88 & 1.36 \\
NC (5\% FM) & 1.48 & 0.65 & 0.83 & 1.27 \\
NC (10\% FM) & 1.40 & 0.59 & 0.80 & 1.34 \\
NC (0\% FM + Protease) & 1.64 & 0.64 & 0.99 & 1.55 \\
NC (5\% FM + Protease) & 1.43 & 0.65 & 0.78 & 1.19 \\
NC (10\% FM + Protease) & 1.35 & 0.59 & 0.76 & 1.27 \\
\hline
\end{tabular}

PC: Positive control. NC: Negative control. MGP: mean gross profit. MFC: mean feeding cost. MDC: mean gross margin. PI: profitability.

The current analysis shows that the index was higher for quails fed on PC diets with $0 \%$ and $5 \%$ FM (1.61\%), and thus there were gains in economic efficiency. Hasni et al. (2014) reported greater economic profit when FM (3.5\% inclusion) was used to replace fish meal in diets for broiler chickens for the one-to- 42-day period.

However, further studies should be undertaken with regard to the use of animal-derived meals supplemented with proteases in diets for meat-type quails, and their effects on performance, carcass characteristics, endogenous enzymatic activity, intestinal microbiota and economic profitability index.

\section{Conclusions}

The inclusion of FM impairs meat-type quails' performance at all ages evaluated. NC diets with and without protease worsen the performance of birds compared to PC diets. The best economic profitability is observed for to $5 \%$ inclusion of feather meal in positive control diets.

\section{References}

ADEOLA, O.; COWIESON, A. J. Board-invited review: opportunities and challenges in using exogenous enzymes to improve non-ruminant animal production. Journal of Animal Science, Oxford, v. 89, n. 10, p. 3189-3218, 2011. DOI: $10.2527 /$ jas.2010-37155

ALLEMAN, F.; MICHEL, J.; CHAGNEAU, A. M.; LECLERCG, B. The effects of dietary protein independent of essential amino acids on growth and body composition in genetically lean and fat chickens. British Poultry Science, Abingdon, v. 41, n. 2, p. 214-218, 2000. DOI: $10.1080 / 713654902$

ANJUM, M. S.; CHAUDHRY, A. S. Using enzymes and organic acids in broiler diets. The Journal of Poultry Science, Ibaraki, v. 47, n. 2, p. 97-105, 2010. DOI: 10.2141/jpsa.009082

BARBOSA, K. A.; PINHEIRO, S. R. F.; VIEIRA, D. J.; CARVALHO, D. C. O.; DOURADO, L. R. B.; BONAFÉ, C. M.; NETO, G. L. O. Desempenho e características de carcaça de codornas de corte alimentadas com farelo de crambe. Revista Brasileira de Saúde e Produção Animal, Salvador, v. 18 , n. 2, p. 282-292, 2017. DOI: $10.1590 /$ s1519-99402017000200007

BELlaVer, C.; COSTA, C. A. F.; AVILA, V. S.; FRAHA, M.; LIMA, G. J. M.; HACKENHAR, L.; BALDI, P. Substituição de farinhas de origem animal por ingredientes de origem vegetal em dietas para frangos de corte. Ciência Rural, Santa Maria, v. 35, n. 3, p. 671-677, 2005. DOI: $10.1590 / \mathrm{S} 0103-84782005000300030$

BRANDELLI, A.; SALA, L.; KALIL, S. J. Microbial enzymes for bioconversion of poultry waste into addedvalue products. Food Research International, Burlington, v. 73, p. 3-12, 2015. DOI: 10.1016/j.foodres.2015.01.015

BUTOLO, J. E. Qualidade de Ingredientes na alimentação animal. 2. ed. Campinas: Butolo, JE, 2010. $430 \mathrm{p}$. 
CORRÊA, G. S. S.; SILVA, M. A.; CORRÊA, A. B.; ALMEIDA, V.; FONTES, D. O.; TORRES, R. A.; DIONELLO, N. J. L. Exigências de proteína bruta e energia metabolizável em codornas de corte durante a fase de crescimento. Arquivo Brasileiro de Medicina Veterinária e Zootecnia, Belo Horizonte, v. 59, n. 2, p. 488494, 2007. DOI: 10.1590/S0102-09352007000200032

DEAN, D. W.; BIDNER, T. D.; SOUTHERN, L. L. Glycine supplementation to low protein, amino acidsupplemented diets supports optimal performance of broiler chicks. Poultry Science, Champaign, v. 85, n. 2, p. 288-296, 2006. DOI: $10.1093 / \mathrm{ps} / 85.2 .288$

DING, X. M.; LI, D. D.; LI, Z. R.; WANG, J. P.; ZENG, Q. F.; BAI, S. P.; SU, Z. W.; ZHANG, K. Y. Effects of dietary crude protein levels and exogenous protease on performance, nutrient digestibility, trypsin activity and intestinal morphology in broilers. Livestock Science, Amsterdã, v. 193, p. 26-31, 2016. DOI: 10.1016/j. livsci.2016.09.002

EYNG, C.; NUNES, R. V.; ROSTAGNO, H. S.; ALBINO, L. F. T.; NUNES, C. G. V.; POZZA, P. C. Composição química e aminoacídica e coeficientes de digestibilidade verdadeira dos aminoácidos de farinhas de penas e sangue determinados em galos cecectomizados. Revista Brasileira de Zootecnia, Viçosa, v. 41, n. 1, p. 80-85, 2012. DOI: $10.1590 / \mathrm{s} 1516-35982012000100012$

FARAG, A. M.; HASSAN, M. A. Purification, characterization and immobilization of keratinase from Aspergillus oryzae. Enzyme and Microbial Technology, Amsterdã, v. 34, n. 2, p. 85-93, 2004. DOI: 10.1016/j. enzmictec.2003.09.002

GUPTA, R.; RAMNANI, P. Microbial keratinases and their prospective applications: an overview. Applied Microbiology and Biotechnology, Berlin, v. 70, n. 1, p. 21-33, 2006. DOI: 10.1007/s00253-005-0239-8

HASNI, M. S.; SAHITO, H. A.; MEMON, M. A.; SANJRANI, M. I.; GOPANG, M. A.; SOOMRO, N. A. Effect of feeding various levels of feather meal as a replacement of fish meal on the growth of broiler. International Journal of Agriculture Innovations and Research, Bhopal, v. 3, n. 2, p. 505-511, 2014.

HOLANDA, M. A. C.; LUDKE, M. C. M. M.; LUDKE, J. V.; HOLANDA, M. C.; RABELLO, C. B. V.; DUTRA JÚNIOR, W. M.; VIGODERIS, R. B.; COSTA, A. A. G. Desempenho e características de carcaças de frangos de corte recebendo dietas com farinha de penas hidrolisada. Revista Brasileira de Saúde e Produção Animal, Salvador, v. 10, n. 3, p. 696-707, 2009.

KHOSRAVINIA, H.; AZARFAR, A.; SOKHTEHZARY, A. Effects of substituting fish meal with poultry by- product meal in broiler diets on blood urea and uric acid concentrations and nitrogen content of litter. The Journal of Applied Animal Research, Abingdonon-Thames, v. 43, n. 2, p. 191-195, 2015. DOI: $10.1080 / 09712119.2014 .963085$

LEITE, P. R. S. C.; LEANDRO, N. S. M.; STRINGHINI, J. H.; CAFÉ, M. B.; GOMES, N. A.; JARDIM FILHO, R. M. Desempenho de frangos de corte e digestibilidade de rações com sorgo ou milheto e complexo enzimático. Pesquisa Agropecuária Brasileira, Brasília, v. 46, n. 3, p. 280-286, 2011. DOI: 10.1590/s0100$204 \times 2011000300008$

LEESON, S.; SUMMERS, J. Nutrition of the chicken. $4^{\text {th }}$ ed. Washigton D.C., Washigton State: Leeson, S. Summers, J. 2001. 591 p.

MACARI, M.; MAIORKA, A. Fisiologia das aves comerciais. Jaboticabal: FUNEP, 2017. 806 p.

MAHMOOD, T.; MIRZA, M. A.; NAWAZ, H.; SHAHID, M. Exogenous protease supplementation of poultry byproduct meal-based diets for broilers: Effects on growth, carcass characteristics and nutrient digestibility. Journal of Animal Physiology and Animal Nutrition, Berlin, v. 102, n. 1, p. 233-241, 2018. DOI: 10.1111/jpn.12734

MARCONDES, N. R.; TAIRA, C. L.; VANDRESEN, D. C.; SVIDZINSKI, T. I. E.; KADOWAKI, M. K.; PERALTA, R. M. New feather-degrading filamentous fungi. Microbial Ecology, Berlin, v. 56, n. 1, p. 13-17, 2008. DOI: $10.1007 / \mathrm{s} 00248-007-9319-\mathrm{x}$

MEYER, B.; BESSEI, W.; VAHJEN, W.; ZENTEK, J.; HARLANDER-MATAUSCHEK, A. Dietary inclusion of feathers affects intestinal microbiota and microbial metabolites in growing Leghorn-type chickens. Poultry Science, Champaign, v. 91, n. 7, p. 1506-1513, 2012. DOI: $10.3382 /$ ps.2011-01786

NUNES, J. O.; ABREU, R. D.; BRITO, J. A. G.; SILVA, R. F.; OLIVEIRA, L. S.; JESUS, N. A. Enzyme supplementation of broiler feeds with reduced mineral and energy levels. Revista Brasileira Ciencia Avicola, Campinas, v. 17, p. 15-21, 2015. Número Especial. DOI: 10.1590/1516-635xspecialissuenutrition-poultryfeeding additives $015-022$

PACHECO, G. F. E.; PEZZALI, J. G.; KESSLER, A. M.; TREVIZAN, L. Inclusion of exogenous enzymes to feathers during processing on the digestible energy content of feather meal for adult dogs. Revista Brasileira de Zootecnia, Viçosa, v. 45, n. 6, p. 288-294, 2016. DOI: 10.1590/s1806-92902016000600002

PINHEIRO, S. R. F.; DUMONT, M. A.; PIRES, A. V.; BOARI, C. A.; MIRANDA, J. A.; OLIVEIRA, R. G.; FERREIRA, C. B. Rendimento de carcaça e qualidade 
da carne de codornas de corte alimentadas com rações de diferentes níveis de proteína e suplementadas com aminoácidos essenciais. Ciência Rural, Santa Maria, v. 45, n. 2, p. 292-297, 2015. DOI: 10.1590/01038478 cr20120327

RABIE, M. H.; HAYAM, M. A.; EL-MAATY, A. Growth performance of japanse quail as affected by dietary protein level and enzyme supplementation. Asian Journal of Animal Veterinary Advances, Deira, v. 10, n. 2, p. 74-85, 2015. DOI: 10.3923/ajava.2015.74.85

ROSTAGNO, H. S.; ALBINO, L. F. T.; DONZELE J. L.; GOMES, P. C.; OLIVEIRA, R. F.; LOPES, D. C.; FERREIRA, A. S.; BARRETO, S. L. T.; EUCLIDES, R. F. Tabelas brasileiras para aves e suínos: composição de alimentos e exigências nutricionais. 3. ed. Viçosa, MG: Rostagno HS, 2011. 252 p.

SISTEMA PARA ANÁLISE ESTATÍSTICA E GENÉTICA - SAEG. Versão 8.0. Viçosa, MG: Fundação Arthur Bernardes, 2007. 59 p. (Manual do usuário).

SAKOMURA, N. K.; ROSTAGNO, H. S. Métodos de pesquisa em nutrição de monogástricos. 2. ed. Jaboticabal, SP, FUNEP, 2016. 262 p.

SANTOS, A. L. S.; GOMES, A. V. C.; PESSÔA, M. F.; MOSTAFÁ, S.; CURVELlO, F. A. Níveis de inclusão de farinha de penas na dieta sobre o desempenho e características de carcaça de codornas para corte. Acta
Scientiarum. Animal Science, Maringá, v. 28, n. 1, p. 2730, 2006. DOI: 10.4025/actascianimsci.v28i1.661

SCHROOYEN, P. M. M.; DIJKSTRA, P. J.; OBERTHÜR, R. C.; BANTJES, A.; FEIJENY, J. Stabilization of solutions of feather keratins by sodium dodecyl sulfate. Journal of Colloid and Interface Science, Amsterdã, v. 240, n. 1, p. 30-39, 2001. DOI: 10.1006/jcis.2001.7673

SILVA, J. H. V.; COSTA, F. G. P. Tabela para codornas japonesas e europeias. 2. ed. Jaboticabal, SP: Silva JHV, 2009. 110 p.

SKLAN, D.; PLAVNIK, I. Interactions between dietary crude protein and essential amino acid intake on performance in broilers. British Poultry Science, v. 43, n. 3, p. 442-449, 2002. DOI: 10.1080/00071660120103710

TEIXEIRA, B. B.; PIRES, A. V.; VELOSO, R. C.; GONÇALVES, F. M.; DRUMOND, E. S. C.; PINHEIRO, S. R. F. Desempenho de codornas de corte submetidas a diferentes níveis de proteína bruta e energia metabolizável. Ciência Rural, Santa Maria, v.43, n.3, p. 524-529, 2013. DOI: $10.1590 / \mathrm{s} 0103-84782013005000014$

XAVIER, S. A. G.; STRINGHINI, J. H.; BRITO, A. B.; ANDRADE, M. A.; CAFÉ, M. B.; LEANDRO, N. S. M. Feather and blood meal in pre-starter diets for broilers. Revista Brasileira de Zootecnia, Viçosa, v. 40 , n. 8 , p. $1745-1752$, 2011. DOI: 10.1590/S151635982011000800018 